\title{
Kualitas Laba Perusahaan Industri Dasar Dan Kimia: Beserta Faktor-Faktornya
}

\author{
Puput Novel $^{1}$, Imam Hidayat ${ }^{2}$, Dirvi Surya Abbas $^{3}$ \\ Universitas Muhammadiyah Tangerang ${ }^{1,2,3}$ \\ Koresponden Email : puputnovel972@gmail.com
}

\begin{abstract}
Abstrak: Dalam penelitian ini dibuat berdasarkan dengan tujuan untuk mengetahui pengaruhnya Struktur modal, ukuran perusahaan, komite audit, kepemilikan manajerial dan Good Corporate Governance terhadap kualitas laba. Dalam penelitian ini memiliki suatu variabel dependen yaitu Kualitas laba $(Y)$. perkumpulan data dalam penelitian ini meliputi sub sektor perusahaan Industri dasar dan kimia yang terdaftar didalam Bursa Efek Indonesia (BEI) pada priode 2015-2018 yang memiliki data perusahaan berjumlah 68 data, dengan menggunkan metode penggambilan data purposive sampling dan memiliki 17 data perusahaan yang memenuhi kriteria penggambilan data sampel, dalam penelitian ini menggunakan suatu analisis regresi data panel dengan menggunakan aplikasi Eviews 9, dalam penelitian ini menghasilkan suatu variabel yang berpengaruh terhadap kualitas laba yaitu variabel ukuran perusahaan dan Good Corporate Governance dalam variabel tersebut memiliki suatu arah negative terhadap kualitas laba dan variabel lainnya tidak memeiliki pengaruh terhdap kualitas laba seperti ( struktur modal, komite audit dan kepemilikan manajerial).

Kata Kunci : Struktur Modal, Ukuran Perusahaan, Komite Audit, Kepemilikan Manajerial, dan Good Corporate Governance
\end{abstract}

Sasaran utama dalam perusahaan ialah dapat menjujung tinggi suatu nilai perusahaan dan memaksimalkan terhadap kualitas laba yang diinginkannya. Rendahnya suatu kulitas laba pada di suatu perusahaan akan membuat daya Tarik para investor berkurang dan bisa menyebabkan suatu nilai perusahaan yang berkurang.

pada PT. Hanjaya Mandala Sampoerna Tbk mengalami kenaikan laba sekitar 23\% dan pada awal tahun 2017 perusahaan mengalami penurunan laba sebesar $0.71 \%$ menjadi Rp. 12,76 triliun. Untuk tahun 2018 perusahaan mengalami peningkatan laba atas penjualan yang meningkat dibandingkan dengan tahun 2017. Tetapi dalam hal tersebut terjadi penyalah sajian laporan keuangan yang merupakan indikasi dari tindakan tidak sehat yang dilakukan oleh manajemen pada kinerja laporan keungan perusahaan pada tahun sebelumnya yang menyebabkan adanya penurunan laba ditahun 2017. Kesalahan dalam laporan keuangan yang diketahui pada akhir tahun 2018 bahwasanya adanya kenaikan hutang cukai sebesar Rp 9,26 triliun yang tidak tertulisa pada kinerja laporan keuangan perusahaan pada tahun 2017.

Menurut Riyanto (2013), ukuran perusahaan adalah besar kecilnya suatu perusahaan dapat dilihat dari besarnya suatu nilai Equity, nilai penjualan atau nilai aktiva. Menurut (Abbas et al., 2019) (2007 : 78),

Struktur Modal adalah perimbangan jumlah hutang jangka pendek yang bersifat tetap, hutang jangka panjang, saham preferen,dan saham biasa.

Menurut Hiro Tugiman ( 2005: 8 ) komite audit adalah sekelompok orang yang dipilih oleh kelompok yang lebih besar untuk mengerjakan 
pekerjaan tertentu atau untuk melakukan tugas -tugas khusus atau sejumlah anggota Dewan Komisaris perusahaan klien yang bertanggung jawab untuk membantu auditor dalam mempertahankan independesinya dari manajemen. Menurut Sulistyanto dan Wibisono (2003) Mengemukakan bahwa good corporate Governance atau tata kelola perusahaan yang baik dapat didefinisikan sebagai sistem yang mengatur dan mengendalikan perusahaan untuk menciptakan nilai tambah bagi stakeholder.

Kepemilikan manajerial tingkat kepemilikan saham oleh pihak manajemen secara aktif terlibat didalam pengambilan keputusan, pengukurannya dilihat dari besarnya proporsi saham yang dimilki manajemen pada akhir tahun yang disajikan dalam bentuk presentase ( Yadnyana dan Wati, 2011).

Tujuan Penelitian ini adalah untuk mendapatkan bukti empiris dalam suatu penelitian pada :

1. Menganalisa pengaruh struktur modal terhadap kualitas laba

2. Menganalisa pengaruh Ukuran perusahaan terhadap kualitaslaba

3. Menganalisa pengaruh komite audit terhadap kualitas laba

4. Menganalisa Good Corporate Governance terhadap kualitas laba

\section{METODE}

Dalam penelitian ini termasuk dalam penelitian konotatif (hubungan), yaitu penelitian yang bertujuan untuk mengetahui hubungan dari dua variabel atau lebih variabel. Berdasarkan penjelasan dari variabelnya maka penelitian ini bersifat konotatif kausal, yaitu penelitian yang mencari hubungan (pengaruh ) sebab dan akibat yang bertujuan untuk mengetahui pengaruh antara variabel independen terhadap dependen (sugiyono,2012).Dalam penelitian ini mengunakan jenis data dan analisis yang digunakan dalam penelitian termasuk dalam penelitian kuantitatif karena mengacu pada perhitungan data yang berupa data, sampel dalam penelitian ini adalah perusahaan industri dasar yang terdaftar di Bursa Efek Indonesia (BEI). Pengambilan sampel dalam penelitian ini mengunakan metode purposive sampling yaitu teknik penentuan sampel dengan pertimbangan tertentu (Sugiyono, $2017: 67$ ), analisis data yang digunakan adalah analisis Statistik descriptive dan Regresi data panel.

\section{HASIL}

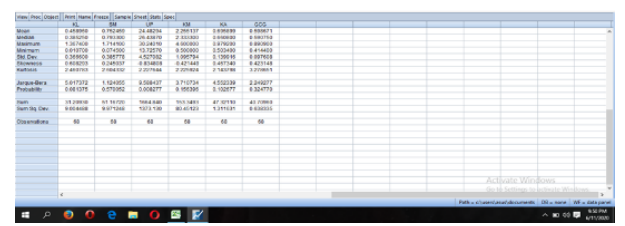

Gambar 1 :Analisis Statistik Deskriptif 


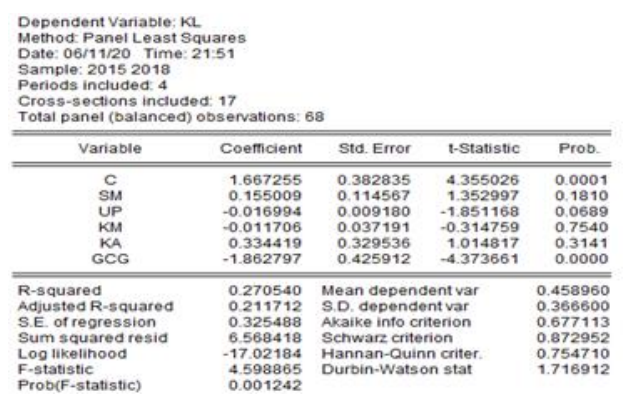

Gambar 2 : Common Effect Model

Dalam hasil output tersebut dapat disimpulkan bahwa variabel ukuran perusahaan (UP), Good Corporate Governance (GCG) dapat berpengaruh terhadap kualitas laba, karena memiliki nilai probanilitas $<0,05$ dan variabel lainnya tidak berpengaruh terhadap kualitas laba karena nilai probabilitas $>0,05$ serta memiliki Nilai Adjusted R-square sebesar 0,211712 sehingga menunjukan bahwa $21,17 \%$ variabel independen penelitian ini menjelaskan tentang kualitas laba dan sisanya sebesar $78,83 \%$ dipenjelasan oleh variabel lain diluar dari penelitian ini. ( $F$ statistik) ialah $0.001242<0.05$ sehingga variabel independen dalam penelitian ini memiliki pengaruh terhadap kualitas laba.

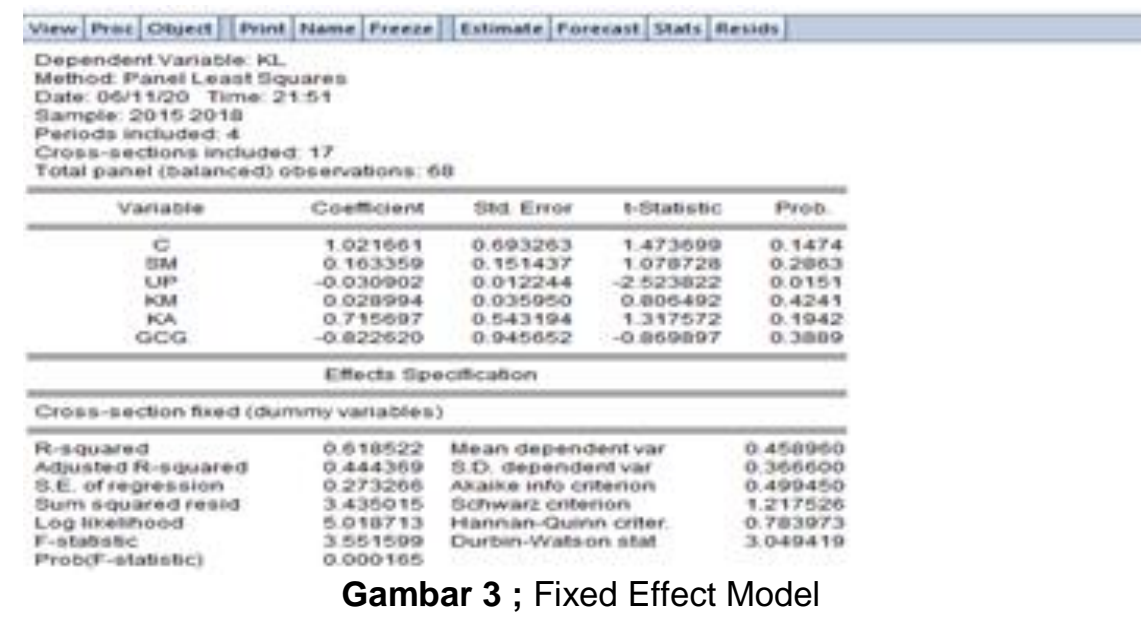

Dalam hasil output Eviews 9 dalam model FEM dapat dilihat bahwasanya variabel Ukuran perusahaan (UP) dapat berpengaruh terhadap kualitas laba karena memiliki Nilai probabilitas sebesar 0.0151 yang artinya $<0.05$ dan variabel lainnya tidak berpengaruh terhadap kualitas laba karena memiliki nilai probabilitas $>0,05$ dan memiliki nilai adjusted R-square sebesar 0,444369 sehingga menujukan bahwasanya $44,43 \%$ variabel dipenelitian ini menjelaskan kualitas laba, sehingga 55,57\% dijelaskan oleh variabel lain diluar dari penelitian ini. Nilai probabilitas ( $f$-statistik) ialah 0,000165 dapat disimpulkan bahwasanya variabel dalam penelitian ini berpengaruh terhadap kualitas laba karena nilai probabilitas $<0,05$. 


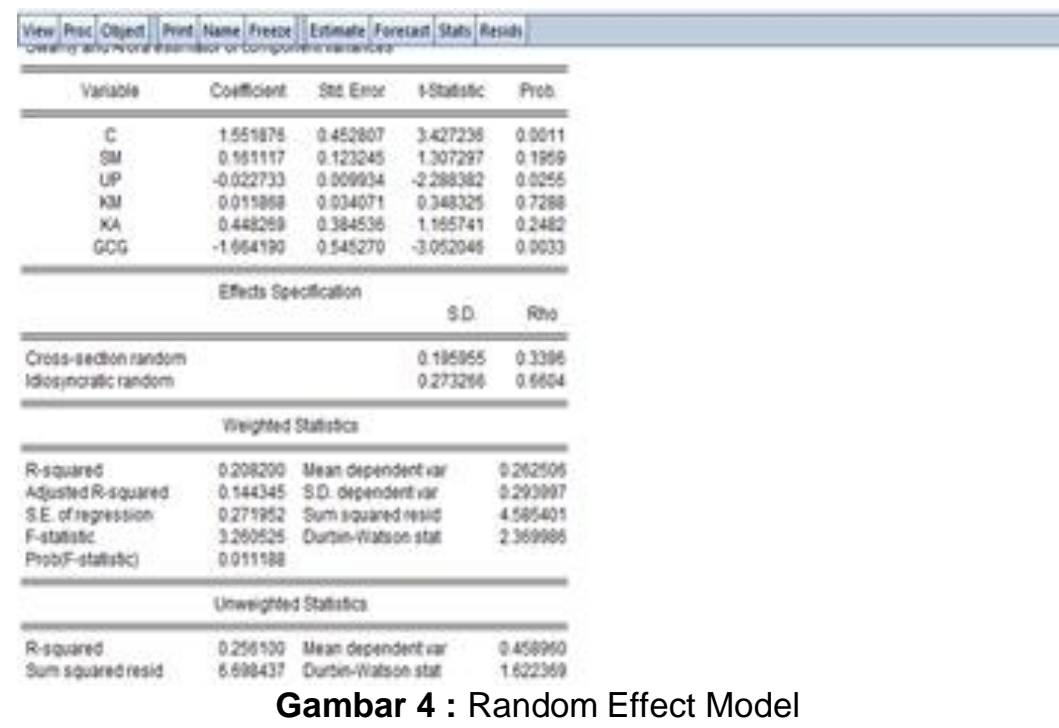

Dalam hasil output model Rem terdapat variabel yang berpengaruh terhadap kualitas laba ialah variabel ukuran perusahaan (UP) dan Good Corporate Governance (GCG) dalam variabel tersebut memiliki nilai Probabilitas $<0.05$ dan variabel lainnya tidak berpengaruh terhadap kualitas laba karena memiliki nilai probabilitas $>0.05$. Nilai adjusted RSquared sebesar 0,144345 atau sebesar $14,43 \%$ sehingga sisa nilai $85,57 \%$ dijelaskan variabel lainnya diluar dari penelitian ini. Nilai Probabilitas (F-statistik) ialah0.011188 atau $<0,05$ dapat disimpulkan bahwasanya variabel independen dalam penelitian ini secara keseluruhan dapat berpengaruh terhadap kualitas laba.

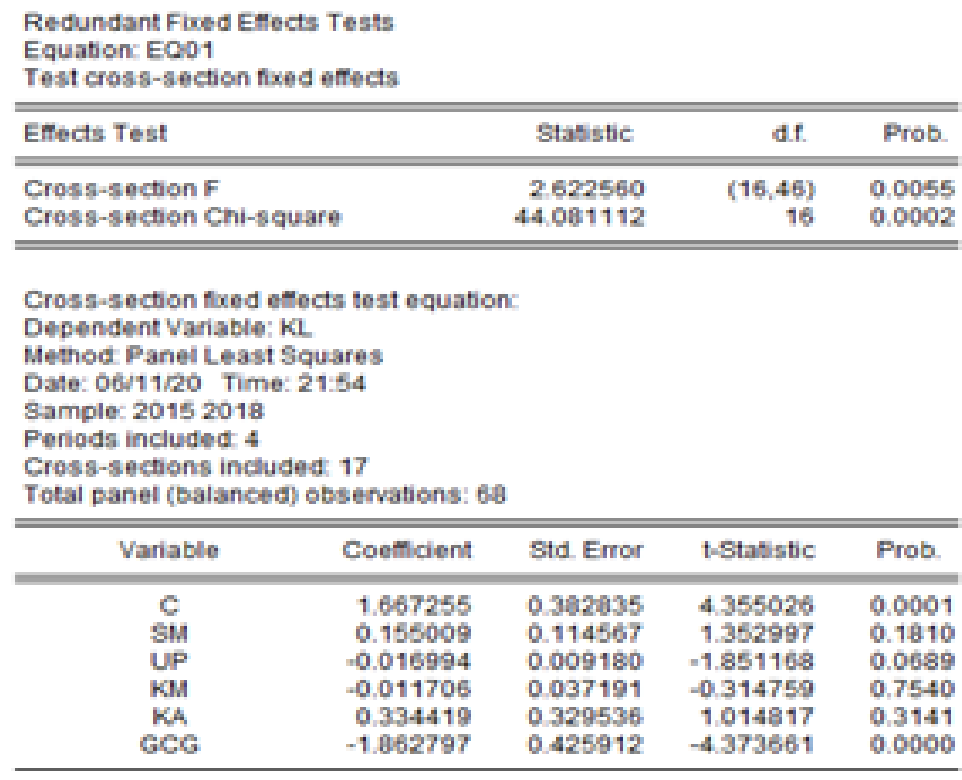

Gambar 5 : Hasil Perhitungan Uji Chow 
Dapat kita lihat pada tabel diatas, memiliki nilai Prob Cross-section $f$ dan Cross-section Chi-square memiliki nilai $<0,05$ maka dapat disimpulkan model FEM lebih layak digunakan dari pada CEM.

\begin{tabular}{|c|c|c|c|c|}
\hline \multicolumn{5}{|c|}{$\begin{array}{l}\text { Corretated Random Effects - Hausman Test } \\
\text { Equabon: EOO1 } \\
\text { Test cross-section random effects }\end{array}$} \\
\hline Test Summary & \multicolumn{2}{|c|}{ Chi-Sq. Statistic } & Chi-Sq det. & Prob. \\
\hline Cross-section random & & 4,405380 & 5 & 0.4926 \\
\hline \multicolumn{5}{|c|}{ Cross-section random effects test companisons: } \\
\hline Variable & Fixed & Random & Var(Dirt) & Prob. \\
\hline $\sin$ & 0.163359 & 0.161117 & 0.007744 & 0.9797 \\
\hline UP & -0.030902 & -0.022733 & 0.000051 & 0.2537 \\
\hline $\mathrm{KM}$ & 0.020994 & 0.011868 & 0.000132 & 0.1355 \\
\hline $\mathrm{KA}$ & 0.715697 & 0.448269 & 0.147192 & $0.495 a$ \\
\hline $\operatorname{CCO}$ & -0.822620 & -1.66 .4190 & 0.596938 & 0.2760 \\
\hline \multicolumn{5}{|c|}{$\begin{array}{l}\text { Cross-section random effects test equation: } \\
\text { Dependent Variable: KL } \\
\text { Method. Panel Least Squares } \\
\text { Date: o6v11120 Time: } 21: 55 \\
\text { Sample: } 20152018 \\
\text { Periods included: } 4 \\
\text { Cross-sections included: } 17 \\
\text { Total panel (balanced) observations: } 68\end{array}$} \\
\hline
\end{tabular}

Gambar 6 : Hasil Perhitungan Uji Hausman

Pada tabel diatas memiliki nilai Prob,Cross-section-random $>0,05$ maka dalam uji hausman REM lebih layak digunakan daripada FEM.

\begin{tabular}{|c|c|c|c|}
\hline & Cross-section & $\begin{array}{l}\text { st Hypothes } \\
\text { Time }\end{array}$ & Both \\
\hline Breusch-Pagan & $\begin{array}{l}5944574 \\
(0.014 a)\end{array}$ & $\begin{array}{l}0.039781 \\
(0.8419)\end{array}$ & $\begin{array}{l}5.984354 \\
(0.0144)\end{array}$ \\
\hline Honda & $\begin{array}{l}2.438150 \\
(0.0074)\end{array}$ & -0.199 .451 & $\begin{array}{l}1.582000 \\
(0.0567)\end{array}$ \\
\hline King-Wvi & $\begin{array}{l}2.438150 \\
(0.0074)\end{array}$ & -0.199451 & $\begin{array}{l}0.705704 \\
(0.2160)\end{array}$ \\
\hline atandardized Honda & $\begin{array}{l}3.233325 \\
(0.0006)\end{array}$ & $\begin{array}{l}0.322992 \\
(0.3734)\end{array}$ & -1.344641 \\
\hline standardized kang-Wu & $\begin{array}{l}3.233825 \\
(0.0006)\end{array}$ & $\begin{array}{l}0.322992 \\
(0.3734)\end{array}$ & -1.562941 \\
\hline Gourienoux, et al: & _ & - & $\begin{array}{l}5.944574 \\
(<0.05)\end{array}$ \\
\hline "Mixed chil-square asym & $\begin{array}{r}\text { lotic citical valu } \\
7.289 \\
4.321 \\
7.965\end{array}$ & & \\
\hline
\end{tabular}

Pada tabel diatas memiliki nilai Prob cross-section Breush pagan $<0.05$ maka dalam uji Lm Model REM lebih layak digunakan dibandingkan model CEM. 
Tabel 1. Hasil Kesimpulan Uji

\begin{tabular}{|c|c|c|c|}
\hline No & Metode & Pengujian & Hasil \\
\hline 1 & Uji Chow & CEM VS FEM & FEM \\
\hline 2 & Uji Hausman & REM VS FEM & REM \\
\hline 3 & Uji Lagrange Multiplaier & CEM VS REM & REM \\
\hline
\end{tabular}

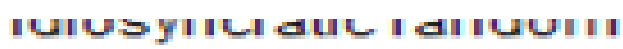

Weighte!

\begin{tabular}{ll}
\hline \hline R-squared & 0.208200 \\
Adjusted R-squared & 0.144345 \\
S.E. of regression & 0.271952 \\
F-statistic & 3.260526 \\
Prob(F-statistic) & 0.011188 \\
\hline \hline
\end{tabular}

Gambar 8 :Hasil Perhitungan Uji F

Pada tabel diatas menunjukkan bahwasanya nilai adjustered R-square sebesar 0,144345 yang artinya tinggi rendahnya kualitas laba dijelaskan oleh variabel UP,SM,KA,KM dan GCG ialah sebesar $14,43 \%$ dan nilai $85,57 \%$ lainnya dijelskan variabel lain diluar dari penelitian ini.

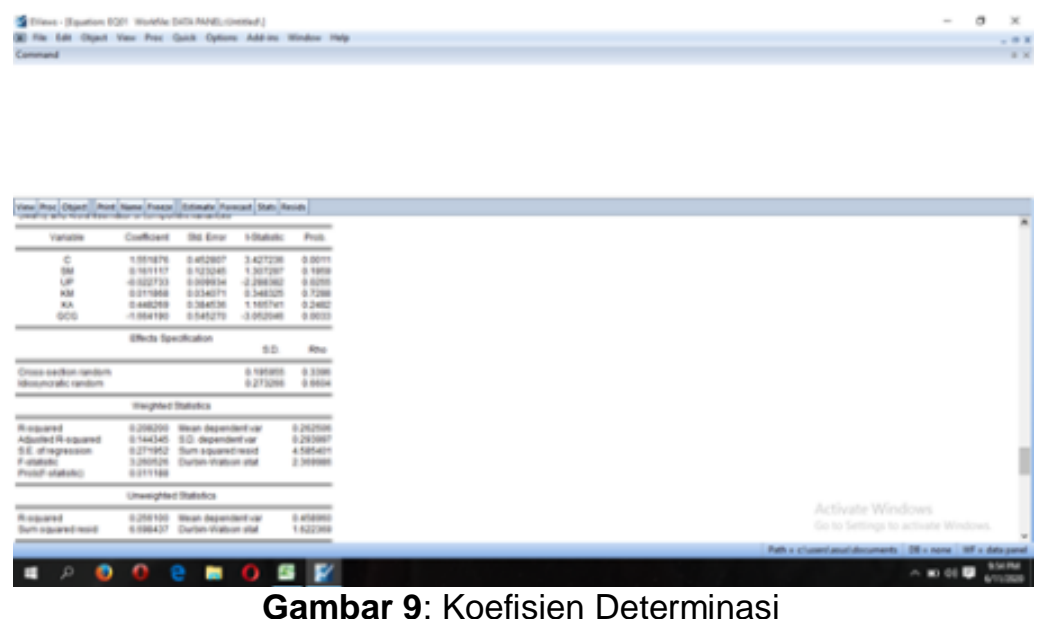

Pada tabel diatas menunjukkan $R$-Squared sebesar 0.14435 artinya bahwa variasi perubahan naik turunnya kualitas laba dapat dijelaskan oleh struktur modal, ukuran perusahaan, komite audit, kepemilikan manajerial dan good corporate governance sementara sisanya sebesar $85,565 \%$ dijelaskan oleh variabel independen lain dilluar dari penelitian ini, 


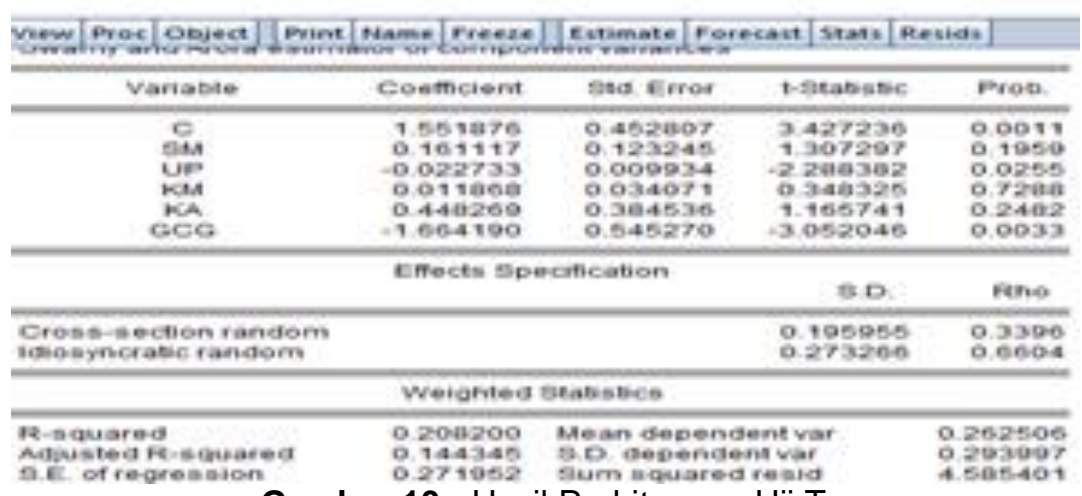

Gambar 10 : Hasil Perhitungan Uji T

Pada data diatas menjelaskan uji T dari variabel UP,SM,KA,KM dan GCG dan yang berpengaruh positif terhadap kualitas laba ialah variabel Ukuran Perusaha (UP) yang memiliki nilai Probabilitas 0,255 atau <0,05 yang berarti memiliki pengaruh terhadap kualitas laba tapi ber-arah negative karena T-statistik bernilai -2,288382.

Stewardship Theory dimana seorang manajer lebih mendepankan dengan tujuan organisasi demi kepuasan principal. Oleh karena itu manajer yang berperan sebagai steward bergerak untuk memenuhi keinginan principal dan tingkat loyalitas terhadap organisasi lebih tinggi sebab steward berusaha untuk mecapai tujuan organisasinya (Rashidpour dan Mazaheri, 2014 ).

Nilai $t$ statistiknya ialah $-2,288382$ dan nilai $t$ tabel tingkat Prob $0,05,(n-k-1)=62$ sebesar 2,52 yang artinya t-statistik UP $<$ dari t tabel nilai probabilitas UP ialah $0,0255<0,05$ dapat disimpulkan bahwa UP berpengaruh terhadap kualitas laba.

Nilai Statistik SM ialah 1,307297 dan nilai t tabel tingkat Prob. $0,05(n-k-1)=62$ sebesar 2,52 yang artinya t-statistik Sm <dari t tabel nilai probabilitas SM $0,1959>0,05$ dapat disimpulkan bahwa SM tidak berpengaruh terhadap kualitas laba.

Nilai Statistik KM ialah 0,348325 dan nilai t tabel tingkat Prob. 0,05 (n-k-1) sebesar 2,52 yang artinya $\mathrm{t}$ statistic $\mathrm{KM}<$ dari $\mathrm{t}$ tabel nilai probabilitas KM ialah 0,7288 > 0.05 dapat disimpulkan bahwa KM tidak berpengaruh terhadap kualitas laba.

Nilai Statistik KA ialah 1,165741 dan nilai t tabel tingkat Prob, 0,05 (n-k-1) sebesar 2,52 yang artinya $t$ statistic $K A<$ dari $t$ tabel nilai probabilitas KA ialah 0,2482 > 0,05 dapat disimpulkan KA tidak berpengaruh terhadap kualitas laba.

Niali Statistik GCG ialah 3,052046 dan t tabel tingkat probabilitas 0,05 (n-k-1) sebesar 2,52 yang artinya t statistic $\mathrm{GCG}<$ dari t tabel nilai probabilitas GCG ialah 0,0033<0,05 dapat disimpulkan GCG berpengaruh positif terhadap kualitas laba.

\section{Keterbatasan}


Berdasarkan hasil pengujian terhadap hipotesis, maka penelitian ini memiliki beberapa keterbatasan diantaranya :

1. Penelitian ini hanya menggunakan sampel perusahaan industri dasar dan kimia, sehingga hasil penelitian ini hanya membuktikan faktorfaktor apa saja yang mempengaruhi kualitas laba dalam perusahaan.

2. Dalam penelitian ini hanya membahas 5 variabel yang terdiri dari , Struktur Modal, Ukuran Perusahaan, Komite Audit , Ukuran Perusahaan dan Good Corporate Governance

3. Periode penelitian relative singkat hanya 4 tahun yaitu selama periode 2015-2018.

\section{KESIMPULAN}

Penlitian ini menggunakan 68 sampel perusahaan Industri dasar dan kimia yang terdaftar di Bursa Efek Indonesia dari tahun 2015 sampai 2018. Berdasarkan hasil analisis dan pembahasan yang telah dilakukan menggunakan regresi data panel, maka diperoleh kesimpulan sebagai berikut :

1. Ukuran perusahaan

Nilai t statistiknya ialah $-2,288382$ dan nilai t tabel tingkat Prob 0,05, (n-k-1) $=62$ sebesar 2,52 yang artinya t-statistik UP $<$ dari t tabel nilai probabilitas UP ialah 0,0255 < 0,05 dapat disimpulkan bahwa UP berpengaruh terhadap kualitas laba.

2. Struktur Modal

Nilai Statistik SM ialah 1,307297 dan nilai t tabel tingkat Prob. 0,05(n-k$1)=62$ sebesar 2,52 yang artinya t-statistik $\mathrm{Sm}<$ dari $\mathrm{t}$ tabel nilai probabilitas SM 0,1959>0,05dapat disimpulkan bahwa SM tidak berpengaruh terhadap kualitas laba

3. Kepemilikan manajerial

Nilai Statistik KM ialah 0,348325 dan nilai t tabel tingkat Prob. 0,05 (n-k-1) sebesar 2,52 yang artinya t statistic $\mathrm{KM}<$ dari $\mathrm{t}$ tabel nilai probabilitas $\mathrm{KM}$ ialah $0,7288>0.05$ dapat disimpulkan bahwa KM tidak berpengaruh terhadap kualitas laba.

4. Komite Audit

Nilai Statistik KA ialah 1,165741 dan nilai t tabel tingkat Prob, 0,05 (n-k-1) sebesar 2,52 yang artinya t statistic $\mathrm{KA}<$ dari $\mathrm{t}$ tabel nilai probabilitas $\mathrm{KA}$ ialah 0,2482 > 0,05 dapat disimpulkan KA tidak berpengaruh terhadap kualitas laba

5.Good Corporate GovernanceNiali Statistik GCG ialah 3,052046 dan t tabel tingkat probabilitas $0,05(n-k-1)$ sebesar 2,52 yang artinya t statistic GCG < dari t tabel nilai probabilitas GCG ialah 0,0033 < 0,05 dapat disimpulkan GCG berpengaruh positif terhadap kualitas laba 


\section{DAFTAR PUSTAKA}

Abbas, D., Hakim, M. Z., \& Istianah, N. (2019). PENGARUH PROFITABILITAS, UKURAN PERUSAHAAN, LEVERAGE, DAN KEPEMILIKAN SAHAM PUBLIK TERHADAP PENGUNGKAPAN CORPORATE SOCIAL RESPONSIBILITY (Pada Perusahaan Makanan dan MinumanYang Terdaftar Di Bursa Efek Indonesia Periode 2014-2017). Competitive Jurnal Akuntansi Dan Keuangan, 3(2), 1-25. https://doi.org/http://dx.doi.org/10.31000/c.v3i2

Heriyanto, A. E. D. F. (2017). Metode Penelitian Akuntansi dan keuangan (Dilengkapi Analisis Regresi Data Panel Dan Regresi Logistik Data Panel Mnggunakan Program Eviews).

Septiyani, G., Rasyid, E., \& Tobing, E. G. (2017). - Faktor-Faktor Yang Mempengaruhi Kualitas Laba Pada Perusahaan Industri Dasar Dan Kimia Yang Terdaftar Di Bursa Efek Indonesia Periode 2012-2015. Management, 2, No.1(1), 70-79.

Udayana, (2014). pengaruh struktur modal likuiditas pertumbuhan laba dan ukuran perusahaan terhadap kualitas laba. ENGARUH STRUKTUR MODAL, PERTUMBUHAN LABA, UKURAN PERUSAHAAN DAN LIKUIDITAS TERHADAP KUALITAS LABA, 100-115.

Rizki Novianti. 2012. Pengaruh Ukuran Perusahaan, Struktur Modal, Kualitas Akrual dan Investment Opportunty Set Terhadap Kualitas Laba pada Perusahaan Manufaktur yang Terdaftar di BEI. Skripsi Mahasiswa Universitas Negeri Semarang.

Rizky Indra Pradita. 2009. Pengaruh Alokasi Pajak Antar Periode, Persistensilaba Akuntansi, Pertumbuhan Laba Akuntansi Struktur Modal, Besaran Perusahaan Terhadap Earnings Response Coefficient Pada Perusahaan Manufaktur Yang Go Public Di BEI. Skripsi Mahasiswa

Boediono, Gideon, 2005 . Kualitas Laba: Studi Pengaruh Mekanisme Corporate Governance dan Dampak Manajemen Laba dengan Menggunakan Analisis Jalur. Simposium Nasional Akuntansi (SNA) VIII Solo

Yuli, WS. Kurniati. 2010. Faktor-Faktor yang Mempengaruhi Kualitas Laba pada Perusahaan Manufaktur di Bursa Efek Indonesia. Skripsi S1, Universitas Muhammadiyah Surakarta.

Reyhan, Arief, et al. 2014 . Pengaruh Komite Audit, Asimetri Informasi, Ukuran Perusahaan, Pertumbuhan Laba Dan Profitabilitas Terhadap Kualitas Laba (Studi Pada Perusahaan Manufaktur yang Terdaftar di BEI 2009-2010). Jom Fekon Vol. 1 No. 2. 